\title{
Cerrahi prosedürler öncesi anti-HCV taraması: Hastalar yeterince bilgi sahibi mi?
}

\author{
Anti-hepatitis C virus screening before surgical procedures: Are patients sufficiently informed?
}

\author{
(D) Nilay DANIŞ ${ }^{1}$, (D)Ayşe ARSLAN², (D)Abdullah Murat BUYRUK ${ }^{3}$, D Fulya GÜNŞAR ${ }^{4}$, (D Ayşın ZEYTINOĞLU², \\ (DImre ALTUĞLU², (DUlus Salih AKARCA4
}

Karabük Üniversitesi Tıp Fakültesi, İç Hastalıkları Anabilim Dalı, ${ }^{1}$ Gastroenteroloji Bilim Dalı, Karabük

Ege Üniversitesi Tıp Fakültesi, ${ }^{2}$ Tıbbi Mikrobiyoloji Anabilim Dalı, ${ }^{4}$ Gastroenteroloji Bilim Dalı, İzmir

Trabzon Kanuni Eğitim ve Araştırma Hastanesi, ${ }^{3}$ Gastroenteroloji Kliniği, Trabzon

\begin{abstract}
Giriș ve Amaç: Direkt etkili anti viral ilaçların kullanılmasılya, hepatit C virüsü enfeksiyonunun tedavisinde başarı oranı \%100'e yaklaşmıştır. Bununla birlikte, birçok hasta teşhis konulmayı beklemektedir. Biz mevcut çalışmada cerrahi öncesi hepatit C virüsü taraması yapılan hastalarda anti-hepatit $C$ virüsü ve hepatit $C$ virüs-RNA pozitifliğinin prevalansını belirlemeyi ve hastalığından habersiz olan hastaların oranını araştırmayı amaçladık. Gereç ve Yöntem: 2012-2015 yılları arasında cerrahi kliniklerinde anti-hepatit C virüsü pozitif saptanan hastalar, hepatit C virüs-RNA pozitifliği ve tedavi geçmişi açısından araştıııldı. Hepatit C virüs-RNA pozitiflıği açııından hastane kayıtları tarandı. Tedavi bilgilerine Medula Sisteminden (Sosyal Güvenlik Sisteminden entegre bir veri tabanı) ulaşıldı. Tedavisiz anti-hepatit C virüsü pozitif hastalara telefonla pozitiflikten haberdar olup olmadıkları soruldu. Bulgular: 4 yıl boyunca 19627 hasta anti-hepatit C virüsü pozitifliği açııından tarandı. 158 hastada (\%0.8) anti-hepatit C virüsü pozitif bulundu (76 erkek, 82 kadın; yaş: $58.2 \pm$ 17.6). Hepatit $C$ virüs-RNA 83 hastada bakılmıştı, 75 hastada hepatit $C$ virüs-RNA testi yoktu. Ulaşılabilen 58 hastanın sadece 14'ü anti-hepatit $C$ virüsü pozitif olduğunu biliyordu. Diğer 44 hasta gastroenteroloji veya enfeksiyon hastalıkları polikliniklerine başvurmaları konusunda uyarıldı. Sonuç: Cerrahi girişim uygulanan 19627 hastanın \%0.8'inde anti-hepatit C virüsü genel Türkiye nüfusuna benzer oranda pozitif bulunmuștur. Hastaların neredeyse yarısında hepatit C virüs-RNA test edilmemiş ve çoğu hasta hepatit C virüsü-RNA'nın test edilmesi ve izlenmesi gerektiği bilgisine sahip değildir. Anti- hepatit C virüsünün cerrahi öncesi taranması yeni hastaların tespiti açııından yetersiz bulunmuştur.
\end{abstract}

Anahtar kelimeler: Anti-HCV pozitifliği, HCV-RNA, serolojik tarama

\section{GíRiș}

Hepatit C (HCV), Türkiye'de kronik hepatitlerin ve karaciğer nakillerinin hepatit $B^{\prime}$ den sonra ikinci sıkliktaki sebebidir $(1,2)$. Doğrudan etkili antivirallerle (DOA) hastaların \%100'e yakınında kür elde edilmiş olmasına rağmen hastaların ancak \%20 kadarı hastalığından haberdar olduğu için sadece yüksek başarılı ilaçlarla hastalı̆ı̆ eradike edilemeyeceği açıktır (3). Bugün için HCV tedavisi yöne-

\footnotetext{
Iletişim: Nilay DANIŞ

Karabük Üniversitesi Eğitim Araştırma Hastanesi, Gastroenteroloji Bölümü Sirinevler Mahallesi Alpaslan Caddesi No: 1 - Karabük

E-mail: nilaydanis17@gmail.com
}

Background and Aims: The success rate of hepatitis $C$ virus treatment is $\sim 100 \%$ after administration of direct-acting antivirals. However, many patients remain undiagnosed. We determined the prevalence of anti-hepatitis $C$ virus and hepatitis C virus-RNA positivity in patients who were screened for hepatitis $C$ virus before surgical procedures and investigated the rate of awareness of their illness. Materials and Methods: Anti-hepatitis C virus screening data were requested and reviewed from all surgical clinics between 2012 and 2015, and positive patients were evaluated for hepatitis C virus-RNA positivity. Treatment data were collected from the Medula System, an integrated database of the Social Security System. Untreated anti-hepatitis $C$ virus positive patients were contacted by phone and asked whether they were aware of their positivity. Results: A total of 19,627 patients were screened for anti-hepatitis C virus during the study period, of which 158 patients (0.8\%) were positive (male: 76; female: 82; age: $58.2 \pm 17.6$ years). Eighty-three patients were tested for hepatitis C virus-RNA, whereas 75 patients were not. Of the 58 patients who could be contacted, 14 were aware of their anti-hepatitis $C$ virus positivity. The remaining 44 patients were alerted to present to the gastroenterology or infectious diseases outpatient clinic. Conclusion: Among the 19,627 patients screened, $0.8 \%$ showed anti-hepatitis C virus positivity, which is similar to the prevalence of anti-hepatitis $C$ virus positivity among the general Turkish population. Almost half of the patients were not tested for hepatitis $C$ virus-RNA, and most of the patients had no information about their anti-hepatitis $C$ virus positivity. These results indicate that pre-surgical anti-hepatitis C virus screening is insufficient for diagnosing new patients.

Key words: anti-HCV positivity, HCV-RNA, serology screening

timinde hedef, hastalı̆ından habersiz hastaların yakalanması için taramalar yapılmasıdır. Taramanın maliyet etkin olması için taranan toplumda HCV prevalansının \%2'nin üzerinde olması gerektiği hesaplanmıştır. Bunun için taramalar daha çok yüksek prevalansa sahip risk gruplarına yoğunlaşmaktadır. Ancak bu yaklaşım ile hastaların en az \%70'ine ulaşılamamaktadır (4). Taramanın acil servi- 
se başvuranlar, tip 2 diyabet vb. HCV'nin ekstrahepatik belirtilerine sahip hastalar gibi yeni popülasyonlara yaygınlaştırılmasına dair çalışmalar bulunmaktadır (5-7). Bunun yanında gerekçesi belli olmamakla beraber cerrahi girişimlerden önce de HCV taraması yapılmaktadır. Bu çalışmada, cerrahi girişimlerden önce yapılan anti-HCV taramasında hepatit $\mathrm{C}$ saptama oranı, anti-HCV pozitif olan olguların hastalıkları hakkında bilgi sahibi olup olmadıkları, tedaviye yönlenip yönlenmedikleri araştırımıştır.

\section{GEREÇ ve YÖNTEM}

Kurumumuz bünyesinde 2012-2015 yılları arasında herhangi bir amaçla ya da cerrahi operasyon öncesi yapılan seroloji testlerinde anti-HCV (+) olan hastalar saptandı. Daha sonra bu hastaların mevcut Medula doktor bilgilerinden daha önce HCV enfeksiyonuna yönelik herhangi bir tedavi alıp almadıkları tespit edildi, mevcut ölüm bildirim sisteminden yine aynı hastaların ölüm kayıtları sorgulandı. Bu sorgulama eğer hasta ölmüşse hasta yakınlarını travmatize etmemek için yapılmıştır. Tüm bu aşamalardan sonra anti-HCV (+) olan ve tedavi almadığı tespit edilen hastalara kurumumuz sistemine kayıtlı olan telefon numaralarından ulaşılarak, mevcut hastalıkları hakkında bilgi sahip olup olmadığı sorgulanmış, hasta eğer isterse birimimize başvurarak tanı ve tedavi için ileri tetkik planlanabileceği ve tedavi olabileceği anlatımıştır. Telefon görüşmeleri iki araştırmacı tarafından (ND, MB) yapılmıştır. Yapılan bu telefon görüşmelerinde hasta mahremiyetine son derece önem verilmiş kişinin kendisi dışında 1. derece akrabalarına bile bilgi verilmemiştir. Bu telefon konuşması şu şekilde gerçekleştirilmiştir.

1. Aranılan kişiye kendini tanıtma

2. Ad-soyad teyit ettirme (Hastanın kendisi dışında herhangi bir yakını ile görüşme yapılmamıştır.)

3. Hastanın yapılacak görüşme ile ilgili onamının alınma$\mathrm{SI}$

4. Daha önce Ege Üniversitesi Tıp Fakültesi Hastanesi bünyesinde herhangi bir nedenle yaptığı başvuruda yapılan incelemeler neticesinde anti-HCV testinin nasıl sonuçlandığına dair bilgisinin olup olmadığının sorulması

5. Hastanın anti-HCV testinin sonucu ile ilgili bilgisi yok ise yüz yüze görüşmek için hastanemize başvuru yapabileceği

6. Hastanın anti-HCV sonucu ile ilgili bilgisi var ise ek tetkik yapılıp yapılmadığı, tedavi alıp almadığı.

\section{İstatistiksel Analiz}

İstatistiksel analiz Windows SPSS programı (version 22.0, SPSS Inc., Chicago, IL) kullanılarak yapılmıştır. Verinin normal dağılım gösterip göstermediği Kolmogorov-Smirnov ve Shapiro-Wilk testleri ile analiz edilmiştir. Normal dağılım gösteren veri için ortalama ve standart sapma analiz edilirken, normal dağılım göstermeyen veri için ortanca, minimum ve maksimum değerleri hesaplanmıştır.

\section{Etik Kurul Onayı}

1964 Helsinki Bildirgesi'nde ve sonrasındaki değişikliklerinde belirtildiği üzere, çalışmamızda tüm yöntemler ulusal araştırma komitesinin etik standartlarına uygun olarak yürütülmüştür. Etik kurul onamı Ege Üniversitesi Tıp Fakültesi Klinik Araştırmalar Etik Kurulu'ndan 7 Ocak 2021 'de 21-1T/55 karar numarası ile alınmıştır. Katılan hastalardan bilgilendirilmiş olur formu alınmıştır.

\section{BULGULAR}

Dört yıl boyunca 19627 hasta anti-HCV pozitifliği açısından tarandı. 158 hasta (\%0.8) pozitif bulundu. Bu 158 hastanın 76'sı erkek, 82'isi kadın idi. Ortalama yaşları $58.2 \pm 17.6$ bulundu. HCV RNA 83 hastada bakılmış, bunlardan 36'sı HCV RNA negatif, 15'i pozitif ve tedavi-naiv, 32 'si ise pozitif ve tedavi deneyimli veya sonradan tedavi edilmiş hastalardı.

Yetmiş beş hastada HCV RNA testi yoktu. Bu hastalar telefonla aranarak anti-HCV pozitifliğinin farkında olup olmadıkları sorulmuştur. Ulaşılabilen 58 hastanın sadece 14 'ü (\%24.1) anti-HCV pozitif olduğunu biliyordu (Şekil 1). Bu 58 hastanın alanin aminotransferaz (ALT) ortalaması $22.5 \pm 11.9$; aspartat aminotransferaz (AST) ortalaması $26 \pm 14.2$; trombosit ortalaması $248 \pm 82.6$ idi. Uluslararası normalleştirilmiş oran (INR) bakılmış olan 51 hasta mevcuttu; ortalaması $1.02 \pm 0.1$ saptandı. Gama glutamil transferaz (GGT) 40 hastada, alkalen fosfataz (ALP) 43 hastada, albümin ise 39 hastada bakılmıştı, ortalamaları sırayla $39.8 \pm 43.7 ; 88.8 \pm 49.8$ ve $4.2 \pm 0.6$ bulundu.

Anti-HCV pozitif olduklarını bilmeyen 44 hastadan $15^{\prime} \mathrm{i}$ il dışında yaşadığından tetkikleri için bulundukları yerdeki gastroenteroloji ya da enfeksiyon hastalıkları polikliniğine başvuracaklarını söyledi. 3 hasta il dışında HCV RNA bakıldığını, negatif geldiğini belirtti. 19 hasta Ege Üniversitesi Gastroenteroloji Bilim Dalı'na başvuracağını söyledi. Aranan 7 hasta il içi başka gastroenteroloji ya da enfeksiyon hastalıkları polikliniklerine başvuracağını söyledi. Kliniğimize geleceğini söyleyen 19 hastanın 15'i başvurdu. Bu hastalardan 3 tanesinin kliniğimizde yapılan HCV 
RNA testi negatif saptandı, 1 hastanın bakılan anti-HCV'si negatif bulundu (Şekil 2). Mevcut bulgularla kendilerine ulaşılmaya çalışılan 58 hasta arasında ve kliniğimize başvuran hastalar arasında dekompanse karaciğer sirozu olan hasta mevcut değildi. Mevcut çalışmada hastalığından habersiz 7 hastaya, toplamda ise 18 hastaya tedavi

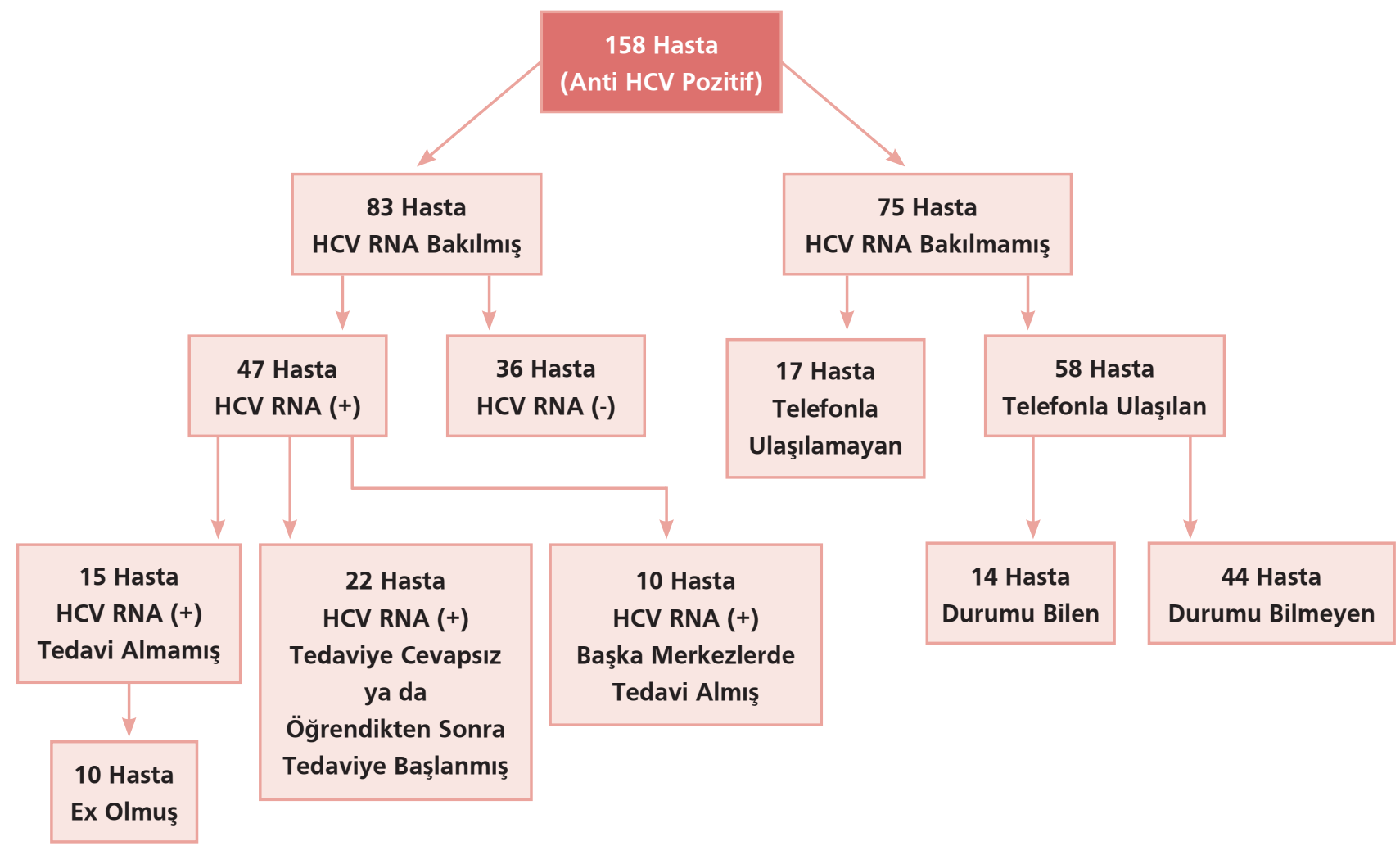

Şekil 1. Anti-HCV pozitif 158 hastanın dökümü

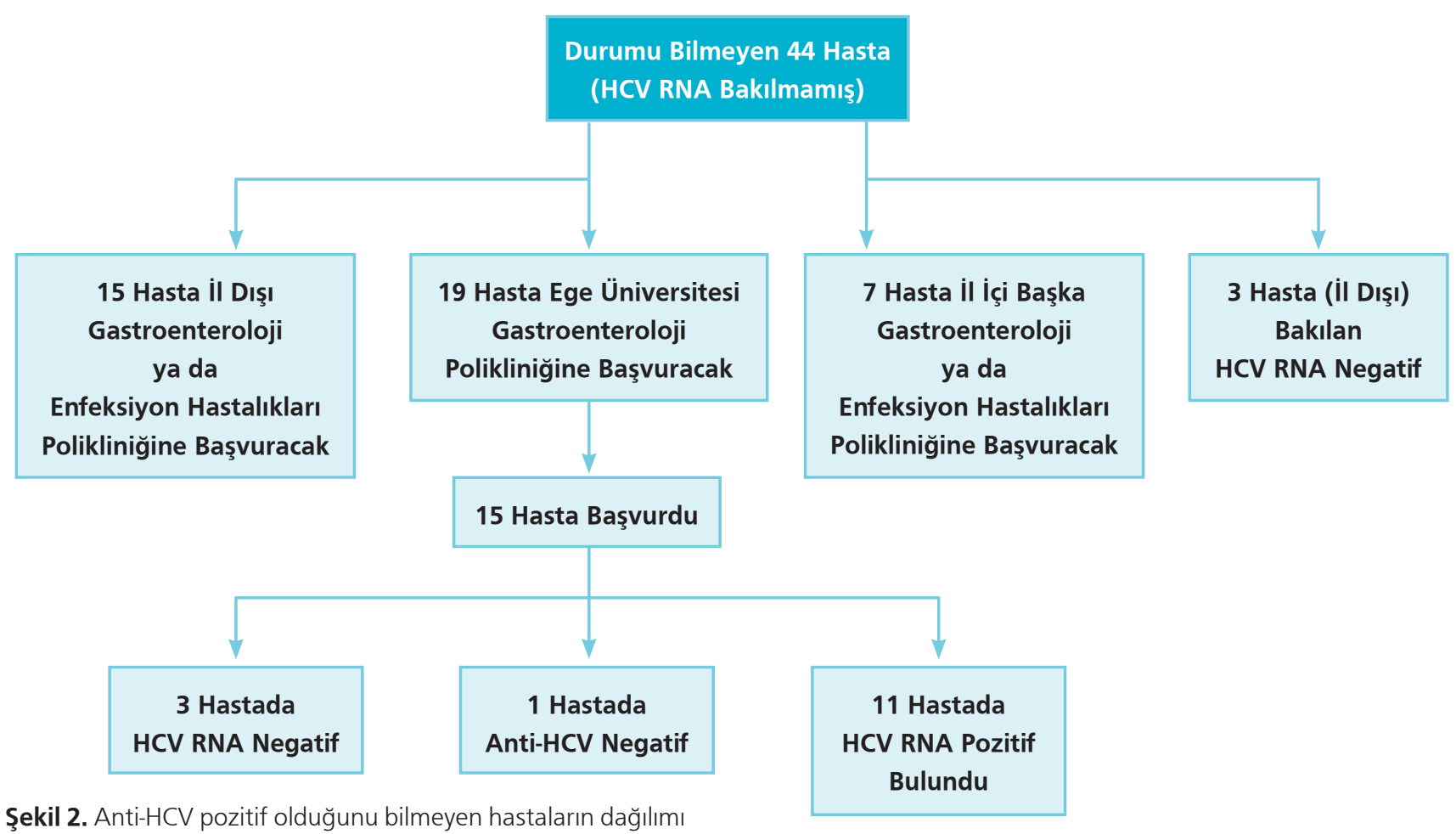


başlandı. Tedavi verilen hastaların $111^{\prime} i$ anti-HCV pozitif olduğunu biliyordu ancak hastalığın tedavi edilebilir olduğunu bilmiyordu. Tedavi edilen tüm hastalarda sustained virolojik yanıt (SVR) 12'ye ulaştı. HCV'den haberi olan ve tedavi başlanan hastaların 3'ü renal transplantlı olguydu. Daha da önemlisi hastalar belirlendikten sonra aileler için önerilen hepatit seroloji taramasında bir hastanın kardeşinde HCV'ye sekonder karaciğer sirozu tanısı konuldu ve tedavi edildi. Üç hasta tedavi almayı kabul etmedi. Tedavi edilen hastalardan ikisi 8 haftalık tedavi ile SVR 12'ye ulaştı. Sekiz haftalık tedavi alan hastalardan biri kendi isteği ile 3. ay ilacını kullanmadı. Diğer hasta yan etkiler nedeniyle 3. ay ilacı kullanamadı.

\section{TARTIŞMA}

HCV enfeksiyonu; erken döneminde asemptomatik olduğu için sinsi seyirli, enfekte olanların \%60-80'inin kronikleştiği, karaciğer sirozunun ve hepatosellüler karsinomun (HCC) en sık sebeplerinden biridir. HCV'nin hem karaciğer sirozunun hem de HCC'nin Türkiye'de 2. sik sebebi olduğu yapılan çalışmalarla ortaya konmuştur $(2,8)$. HCV enfeksiyonu günümüzde başarı ile tedavi edilebilen bir hastalıktır. DOA ilaçların kullanılmasıyla, HCV enfeksiyonunun tedavisinde başarı oranı \%100'e yaklaşmıştır (3). HCV eradikasyonu ile dekompanse karaciğer sirozu hastalarının dekompansasyon bulgularının ve son dönem karaciğer hastalı̆̆ı [Model for End-Stage Liver Disease (MELD)] skorlarının belirgin olarak gerilediği gösterilmiştir. Ayrıca eradikasyonun; kompanse sirozlu hastaların dekompansasyon oranlarını düşürdüğü, portal hipertansiyonu azalttığı, HCC oluşum riskini azalttığı, fibrozisin gerilemesini sağladığı gösterilmiştir (9). Hatta HCC'si olan hastalarda bile HCV eradikasyonunun hepatik rezervi koruduğu, yaşam beklentisini uzattığı da gösterilmiştir (10). Ancak yine de en büyük faydanın hastaları kronik hepatit döneminde yakalayıp tedavi etmek olduğu da ortaya konmuştur. Hastalık ne kadar erken yakalanırsa enfekte kişilerin fayda görme oranı da o kadar artmaktadır (9). DOA ile HCV eradikasyonunun sadece hepatik komplikasyonları azaltmadığı, kardiyovasküler hastalık riskini azalttığı, glisemik kontrol üzerinde etkili olduğuna dair çalışmalar da yayınlanmaktadır $(11,12)$. Bunun yanında siroz aşamasında HCV kürü sağlanan hastalarda, azalmakla beraber, HCC riskinin devam ettiği iyi bilinmektedir. Bu nedenle hastaların olabildiğince erken dönemlerde yakalanmaları ve tedavi edilmeleri esastır. Kür sağlanabilen bir hastalık olduğu için hem sayılan komplikasyonların, hem de bulaştırıcılığın engellenmesi açısından HCV hastalarının tedavi edilmesi çok önemlidir. Dünya Sağlık Örgütü'nün (WHO) 2030 yllına kadar olan süreçte dünya genelinde yeni hepatit C hastalarını \%90, mortaliteyi \%65 azaltma hedefi vardır (13). 2015 ylında yayımlanan TURHEP çalışmasında 2013 yılında Türkiye'de yaklaşık 514000 hastanın HCV ile enfekte olduğu, bu hastaların 5500'ünün yeni tanı aldığı, sadece 4200 hastanın HCV nedeniyle tedavi aldığı hesaplanmış ve bildirilmiştir (1). Buradan da anlaşıldığı üzere daha tedavi olmayı bekleyen hasta grubu tedavi alanlardan çok daha fazladır. Dünya üzerinde de yapılan çalışmalarda HCV ile enfekte hastaların \%50-80'inin tanı alamadığı, sadece \%20'sinden azının uygun tedavi aldığı gösterilmiştir (14). Buna rağmen, birçok hasta geliştirilen tarama politikaları sayesinde teşhis konulmayı beklemektedir. Ne yazık ki, hiçbir ülkede ideal bir HCV tarama programı geliştirilmemiştir. Bu nedenle en azından mikroeliminasyon yapmanın doğru bir strateji olduğu düşünülmektedir. Daha önce yayımlanan pek çok çalışmada riskli grup olduğu belirlenmiş; damardan ilaç kullanıııları, hemodiyalize girenler, cezaevinde olanlar gibi gruplar mikroeliminasyonların akılcı hedefleri gibi görünmektedir. Tarama ve tedavinin hedeflenebileceği diğer bir grup da herhangi bir nedenle tarama yapılan (evlilik öncesi, girişimler öncesi) kişiler arasındaki enfekte kişilerdir. Türkiye'de cerrahların çoğu cerrahi öncesinde hastalardan ampirik olarak hepatit serolojisi istemektedir. Çalışmamızda cerrahi öncesi gönderilen seroloji tetkikleri arasında anti-HCV pozitifliğinin (\%0.8) Türkiye prevalansı ile benzer olduğu ortaya konmuştur. Yeni hastaları saptamak için cerrahi öncesi anti-HCV bakmak yeterli değil gibi görünmektedir. Ayrıca bu seroloji sonucunun hastalar tarafından bilinip bilinmediği, ilgili branşlara gidip gitmediği bilinmemektedir. Bu da cerrahi öncesi gönderilmiş serolojinin yeni hasta yakalamadaki değerini düşürmektedir. Norveç'ten yapılan bir çalışmada HCV ile enfekte kişilerin \%39'unun hastalığından haberdar olmadığı ortaya konmuştur (15). Birleşik Krallık'tan yapılan çalışmada HCV ile enfekte kişilerin sadece \%39'unun hepatolojiye yönlendirildiği, tüm enfekte hastaların sadece \%22'sinin uygun tedavi alabildiği bildirilmiştir (16). Daha önce Türkiye'den yapılan bir çalışmada enfekte kişilerin yaklaşık \%27'sinin HCV ile enfekte olduğunu tarama öncesi bilmediği, bu kişilerin yarıdan fazlasının cerrahı tarafından ya da telefonla bilgilendirildiği, ancak bilgilendirilmeyen enfekte kişilerin de \%33 kadar olduğu gösterilmiştir (17). Yine ülkemizden yapılan diğer bir çalışmada enfekte olan kişilerin \%22'sinin mevcut durumu bilmediği gösterilmiştir (4). Bizim çalışmamızda da telefonla ulaşılabilen hastaların sadece \%24.1'inin durumdan haberdar olduğu ortaya çıkmışıı. Anti-HCV pozitifliğinden haberdar olmayan 44 hastaya bilgi verilerek gastroenteroloji veya enfeksiyon hastalıkları polikliniklerine başvurmaları gerektiği iletilmiştir. Kurumumuz gastroenteroloji polikliniğine başvuranlar arasından hastalığından veya hastalığını bilip hastalığın artık tedavi edilebilir olduğundan haberdar olmayan has- 
taların da içinde olduğu toplam 18 hasta tedavi alabilmiş, hepsi SVR 12'ye ulaşmıştır. Bu hastaların kronik karaciğer hastalığının komplikasyonlarından korunabilecek olması önemlidir. Ancak halen tanı konmayı ve tedavi almayı bekleyen pek çok hasta olduğu da aşikardır. Bu nedenle bir taraftan yeni hastaları yakalamaya yönelik tarama programları geliştirilirken bir taraftan da taranmış olup pozitif saptanmış olan hastaların en azından ilgili polikliniklere yönlendirilmesi uygun olacaktır.

Sonuç olarak, çalışmamızda cerrahi öncesi anti-HCV pozitif saptanan hastaların hastalıkları hakkında yeterince bilgi sahibi olmadığı, tedavi seçeneklerine yeterince ulaşamadığı gösterilmiştir. Bu amaçla tüm hekimlerin bilgi-

\section{KAYNAKLAR}

1. Tozun N, Ozdogan O, Cakaloglu Y, et al. Seroprevalence of hepatitis $B$ and $C$ virus infections and risk factors in Turkey: A fieldwork TURHEP study. Clin Microbiol Infect 2015;21:1020-6.

2. Idilman R, Aydogan M, Oruncu MB, et al. Natural history of cirrhosis: changing trends in etiology over the years. Dig Dis. 2020 Nov 3.

3. Hezode C, Treatment of hepatitis C: Results in life. Liver Int 2018;38(Suppl 1):21-7.

4. Akkuzu MZ, Sezgin O, Yaraş S, et al. Patients lost after anti-HCV-positive finding in a tertiary care university hospital: Increased awareness and action is necessary to eradicate HCV. Med Bull Sisli Etfal Hosp 2019;53:366-70.

5. Prince DS, Pipicella JL, Fraser M, et al. Screening emergency admissions at risk of chronic hepatitis $\mathrm{C}(\mathrm{SEARCH})$ to diagnose or 're-diagnose' infections is effective in Australia. J Viral Hepat 2021;28:1218.

6. Gentile I, Pinchera B, Viceconte $G$, et al. Hepatitis $C$ screening in the Emergency Department of a large hospital in Southern Italy: results of a pilot study. Infez Med 20191;27:32-9.

7. Ndako JA, Owolabi AO, Olisa JA, et. al. Studies on the prevalence of Hepatitis $C$ virus infection in diabetic patients attending a tertiary health-care facility South-west Nigeria. BMC Infect Dis 2020;20:664.

8. Arhan M, Akdoğan M, İbiş $\mathrm{M}$, et al. Data of hepatocellular carcinoma from a single center: A retrospective study. Akademik Gastroenteroloji Dergisi 2009;8:18-23.

9. Calvaruso V, Craxì A. Hepatic benefits of HCV cure. J Hepatol 2020;73:1548-56. lendirilmesinin yapılması, hastane bilgi işlem sistemlerine alarm sistemlerin kurulması başvurulabilecek yöntemler arasındadır. Bu şekilde artık eradikasyonu mümkün olan bir hastalığın eradikasyonunda yol alınabilir.

Etik Kurul Onayı: Ege Üniversitesi Tıp Fakültesi Klinik Araştırmalar Etik Kurulu'ndan 7 Ocak 2021'de 21-1T/55 karar numarası ile etik kurul onayı alınmıştır. Katılan hastalardan bilgilendirilmiş olur formu alınmıştır.

Çıkar Çatışması: Yazarlar herhangi bir çıkar çatışması beyan etmemişlerdir.

Finansal Destek: Yazarlar finansal destek beyan etmemişlerdir.
10. Yeh $\mathrm{ML}$, Kuo HT, Huang $\mathrm{Cl}$, et al. Eradication of hepatitis $\mathrm{C}$ virus preserve liver function and prolong survival in advanced hepatocellular carcinoma patients with limited life expectancy. Kaohsiung J Med Sci 2020 Oct 6. 10.1002/kjm2.12303 [Epub ahead of print]

11. Butt AA, Yan P, Shuaib A, et al. Direct-acting antiviral therapy for $\mathrm{HCV}$ infection is associated with a reduced risk of cardiovascular disease events. Gastroenterology 2019;156:987-96.e8.

12. Graf C, Welzel T, Bogdanou D, et al. Hepatitis C clearance by direct-acting antivirals impacts glucose and lipid homeostasis. J Clin Med 2020;9:2702.

13. Waheed $Y$, Siddiq M, Jamil Z, Najmi MH. Hepatitis elimination by 2030: Progress and challenges. World J Gastroenterol 2018;24:4959-61.

14. Denniston MM, Klevens RM, McQuillan GM, Jiles RB. Awareness of infection, knowledge of hepatitis $C$, and medical follow-up among individuals testing positive for hepatitis C: National Health and Nutrition Examination Survey 2001-2008. Hepatology 2012;55:165261.

15. Kileng H, Gutteberg T, Goll R, Paulssen EJ. Screening for hepatitis $C$ in a general adult population in a low-prevalence area: the Tromsø study. BMC Infect Dis 2019;19:189

16. Adland E, Jesuthasan G, Downs L, et al. Hepatitis virus (HCV) diagnosis and access to treatment in a UK cohort. BMC Infect Dis 2018;18:461.

17. Erbay K, Hızel K, Özdil T. Importance of anti-HCV screening before invasive procedures. Klimik Dergisi 2019;32:229-32. 